\title{
Posterior Escape of Greater Than Half of Bolus
}

National Cancer Institute

\section{Source}

National Cancer Institute. Posterior Escape of Greater Than Half of Bolus. NCI

Thesaurus. Code C127193.

A finding of posterior escape of greater than half of bolus during swallowing. 